\title{
NATURAL INCIDENCE OF ENTOMOPATHOGENIC FUNGUS Nomuraea rileyi ON Spodoptera frugiperda INFESTING CORN IN BENGKULU
}

\author{
Sempurna Ginting ${ }^{1}$, Nadrawati $^{1}$, Agustin Zarkani ${ }^{1}$, \& Teten Sumarni ${ }^{2}$ \\ ${ }^{1}$ Department of Plant Protection, Faculty of Agriculture, University of Bengkulu, Indonesia \\ Jl. W.R Supratman, Kandang Limun Bengkulu 38371 \\ ${ }^{2}$ Dinas Pertanian Seluma \\ Jl. RA. Kartini, Pematang Aur, No.06 Tais, Seluma \\ E-mail: sempurnaginting@unib.ac.id
}

Manuscript received: 5 April 2020. Revision accepted: 8 May 2020

\begin{abstract}
Natural incidence of entomopathogenic fungus Nomuraea rileyi on Spodoptera frugiperda infesting corn in Bengkulu. Spodoptera frugiperda (J. E. Smith) (Lepidoptera: Noctuidae) is a new invasive pest in corn. The intensive use of synthetic insecticides for pest control causing various problems such as resistance, pest resurgence, and environmental damage. To solve these problems, entomopathogenic fungi could be used as an alternative in pest management. Therefore, this study was aimed to determine the natural incidence of Nomuraea rileyi (Farlow) Samson (Hypocreales: Clavicipitaceae) entomopathogenic fungus on S. frugiperda in Bengkulu. The research was carried out by exploring the corn producing areas in Bengkulu for $N$. rileyi incidence. The results showed that the $N$. rileyi was occurred naturally infected $S$. frugiperda larvae reached $79.0 \%$. Meanwhile, the percentage of crops damage due to $S$. frugiperda was ranged from 40.0 to $96.0 \%$. The highest natural incidence of $N$. rileyi were found in the Village of Bukit Barisan and Tugu Rejo (79.0\%), followed by Pulo Geto Baru (25.0\%), and Taba Mulan (5.3\%) while the lowest incidence was in Sidomulyo (1.0\%). The infected larvae were not found in the Napal, Beringin Raya 1, and Beringin Raya 2, despite the percentage of S. frugiperda attacks was reached 50.0; 50.0 and 74.0\%, respectively.
\end{abstract}

Key words: corn, natural incidence, Spodoptera frugiperda, Nomuraea rileyi

\section{INTRODUCTION}

Corn is a strategic national commodity that included in the special program for rice, corn, and soybeans, as Upaya Khusus Padi, Jagung, dan Kedelai (UPSUS PAJALE) from the Ministry of Agriculture. To increase the corn yields, a pest management strategy have to be developed, particularly for important insect pest. Spodoptera frugiperda (J.E. Smith) (Lepidoptera: Noctuidae) is important insect pest of field corn in Indonesia (Trisyono et al., 2019).

A new invasive of armyworm has been discovered in the world, the Fall Armyworm (FAW) or $S$. frugiperda. The $S$. frugiperda attacks crops such as corn, rice, and wheat. $S$. frugiperda is a native pest of the tropics and subtropics in America (Goergen et $a l ., 2016)$ and difficult to control due to the rapid spread of adults. The $S$. frugiperda was reported for the first time on the Africa in 2016 (Goergen et al., 2016), and has attacked more than 30 countries in Africa (Huesing,
2018). This pest had also been reported in Karnataka, India (Sharanabasappa et al., 2018a), specifically in the District of Bihar, Chhattisgarh, Gujarat, Maharashtra, Odisha, Tamil Nadu, Telangana, and West Bengal (EPPO, 2019), Myanmar (Yee et al., 2019), Sri Lanka (Wanasinghe et al., 2019) and Thailand (IPPC, 2018).

Losses due to this pest in 12 countries of Africa was ranged from 8.3 to 20.6 million tons per year, valued 2.481-6.187 million USD/year (Shylesha et al., 2018). Baudron et al. (2019) reported that $S$. frugiperda infestation in corn was ranged from 26.4 to $55.9 \%$ reducing yields of $11.57 \%$. The level of damage to leaves, silk, and corncobs ranged from 25 to $50 \%$ reducing yields of 58.0\% (Chimweta et al., 2019). FAW was first reported on March 2019 in West Pasaman (West Sumatra Province) Indonesia and caused major damage with larvae population reached 2-10 larvae per plant (Nonci et al., 2019). S. frugiperda has also been reported in Lampung Province (Trisyono et al., 2019; Lestari et al., 2020) and West Java Province (Maharani 
et al., 2019). Early et al. (2018) explained that the spread of $S$. frugiperda can occur through the trade of vegetables and fruits between countries.

Farmers have used some techniques such as insect-resistant plant, insecticides, and biological control for the pests. Environmentally friendly pest control including the use of entomopathogenic fungi could help reducing the use of pesticides and harmful effects on the environment. In contrast to bacterial and viral pathogens of insects, entomopathogenic fungi have the ability to infect the pest by producing enzymes and penetrating the host cuticle. In addition, it also have the potential to cause epizootics during favorable environmental conditions.

Nomuraea rileyi is an entomopathogenic fungus that causes natural infections in various Lepidoptera. This fungus has been reported to infect $S$. frugiperda in Karnataka, India (Sharanabasappa et al., 2018b). Mallapur et al. (2018) reported that $N$. rileyi was able to reduce damage to corn leaves caused by S. frugiperda from 62.50 to $73.05 \%$. N. rileyi could also cause epizootics in Lepidoptera such as Heliothis zea, Plathypena scabra, Bombyx mori, Pseudoplusia includens, Anticarsia gemmatalis, and some Coleoptera (Moanaro et al., 2017). N. rileyi was able to cause mortality of 2 nd instar of $S$. frugiperda larvae, neonates, and egg (Akutse, 2019; Cruz-Avalos et al., 2019). However, information about the natural incidence of $N$. rileyi in $S$. frugiperda which infested corn in Bengkulu has never been reported. The purpose of this study was to determine the natural incidence of $N$. riley $i$ in $S$. frugiperda in the field.

\section{MATERIALS AND METHODS}

Research Site. This research was carried out in several corn fields: Sidomulyo and Napal Villages, Seluma District; Pulo Geto Baru, Taba Mulan, Bukit Barisan, Tugu Rejo Villages, Kepahiang District; Beringin Raya 1 and Beringin Raya 2 Villages, Bengkulu City (Figure $1)$.

Sampling and Identification. The survey was conducted from April to November 2019 in the area of corn production in Bengkulu using scouting system (McGrath et al., 2018). The number of samples was 50

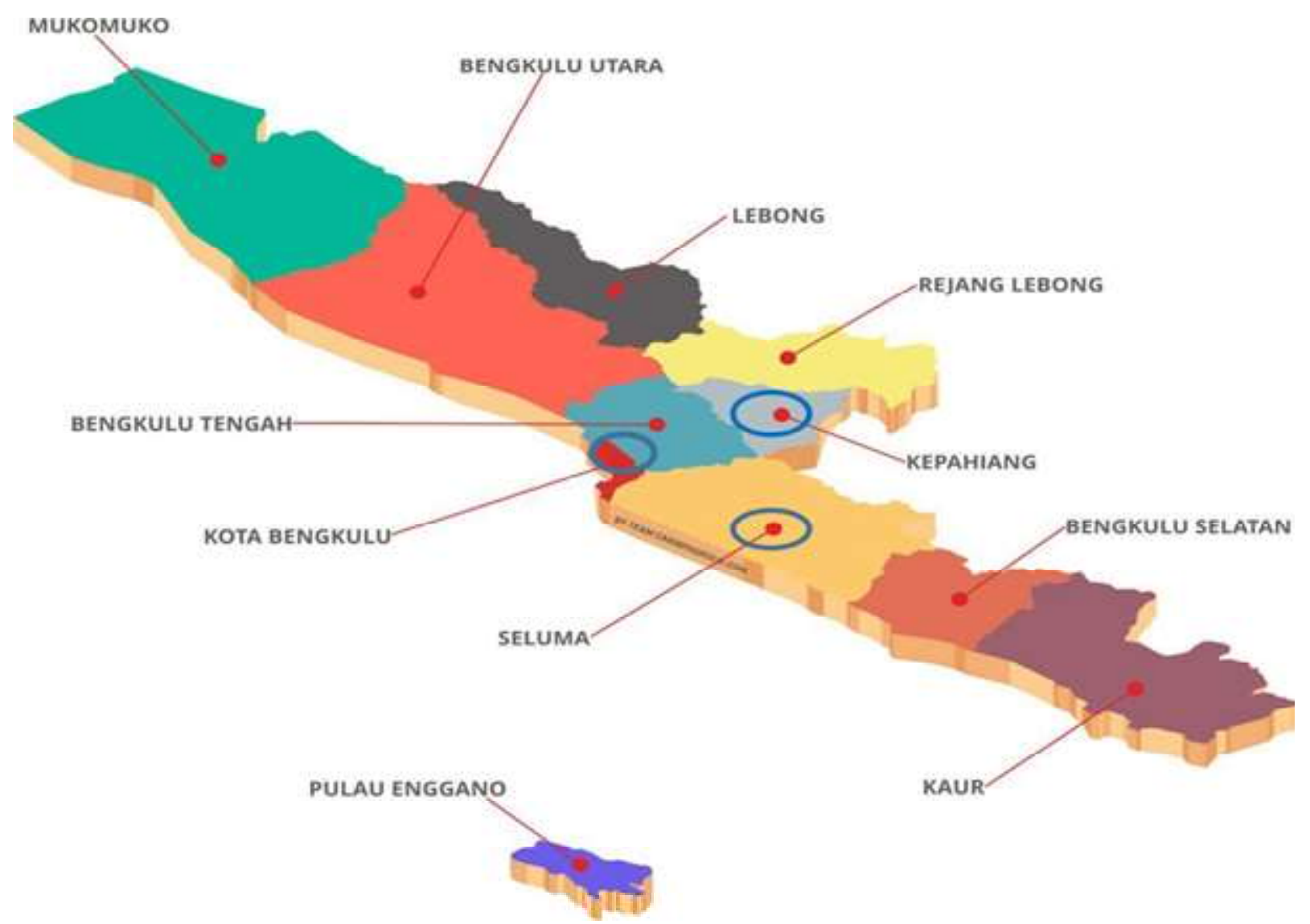

Figure 1. Map of research site (blue circle is an area of research). Source: https:/www.google.com/ search?q=peta+bengkulu\&safe. 
plants per location. Identification of insect and entomopathogenic fungi was carried out at the Plant Protection Laboratory, Faculty of Agriculture, University of Bengkulu. Larvae found were also taken to the Laboratory for rearing to imago and morphologically identified.

Observation of Symptoms and Population of Spodoptera frugiperda Larvae. Observation of symptoms of $S$. frugiperda attacks was carried out directly on all parts of the corn crops. The symptoms were then confirmed by examining the larvae in the leaf rolls and then photographed. The number of larvae was counted.

The Incidence of Spodoptera frugiperda and Nomuraea rileyi in the Corn Planting Area. The corn areas from each district were surveyed and identified for the incidence of $S$. frugiperda and $N$. rileyi. From each location, a total of 50 plants were observed. The number of larvae infected by $N$. rileyi was recorded and the percentage was calculated. The percentage of pest attacks and the incidence of $N$. riley $i$ were calculated using the following formula (Mallapur et al., 2018):

The crop damage percentage $=\frac{\sum \text { damage crops }}{\sum \text { overall crops }} \times 100 \%$ The incidence of N.rileyi $=\frac{\sum \text { larvae infected with } N . \text { rileyi }}{\sum \text { overall larvae }} \times 100 \%$

Observation of $N$. rileyi was conducted by observing dead larvae infected by pathogens, and then the larvae were taken to the laboratory to be isolated and morphologically identified using a binocular microscope based on Dutta et al. (2014).
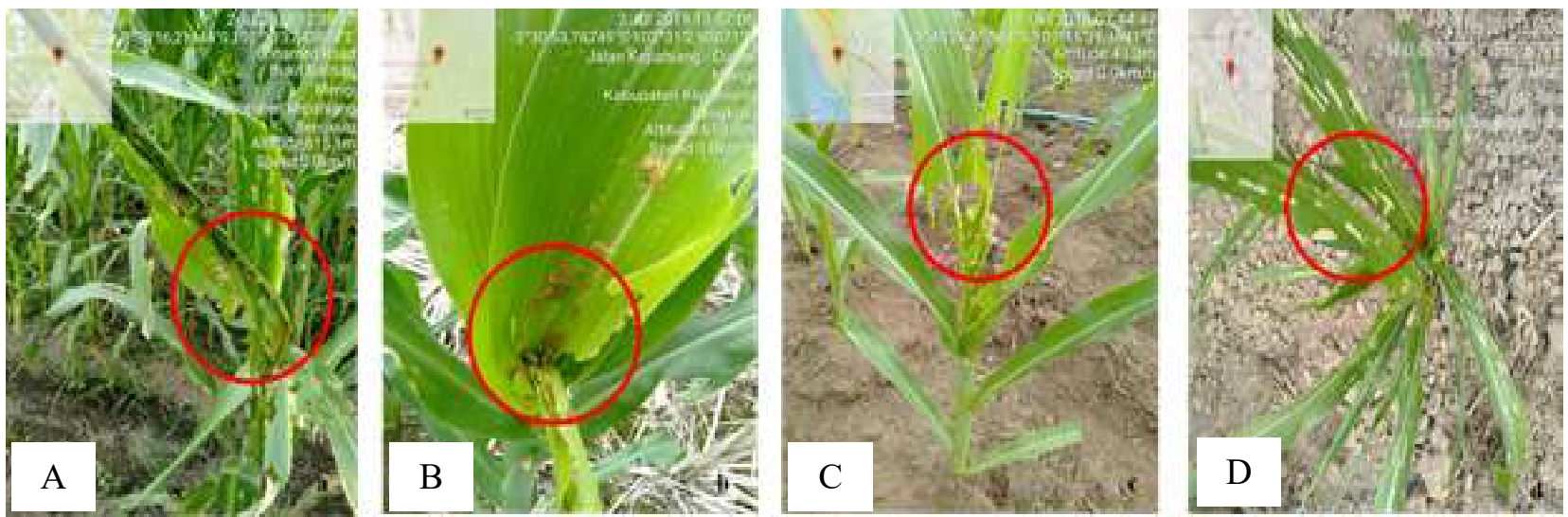

Figure 2. Symptoms of S. frugiperda in various areas of corn. (A) Bukit Barisan, Merigi Sub District, Kepahiang District, (B) Pulo Geto Baru, Merigi Sub District, Kepahiang District, (C) and (D) Beringin Raya 1 and Beringin Raya 2, Muara Bangka Hulu Sub District, Bengkulu City. 

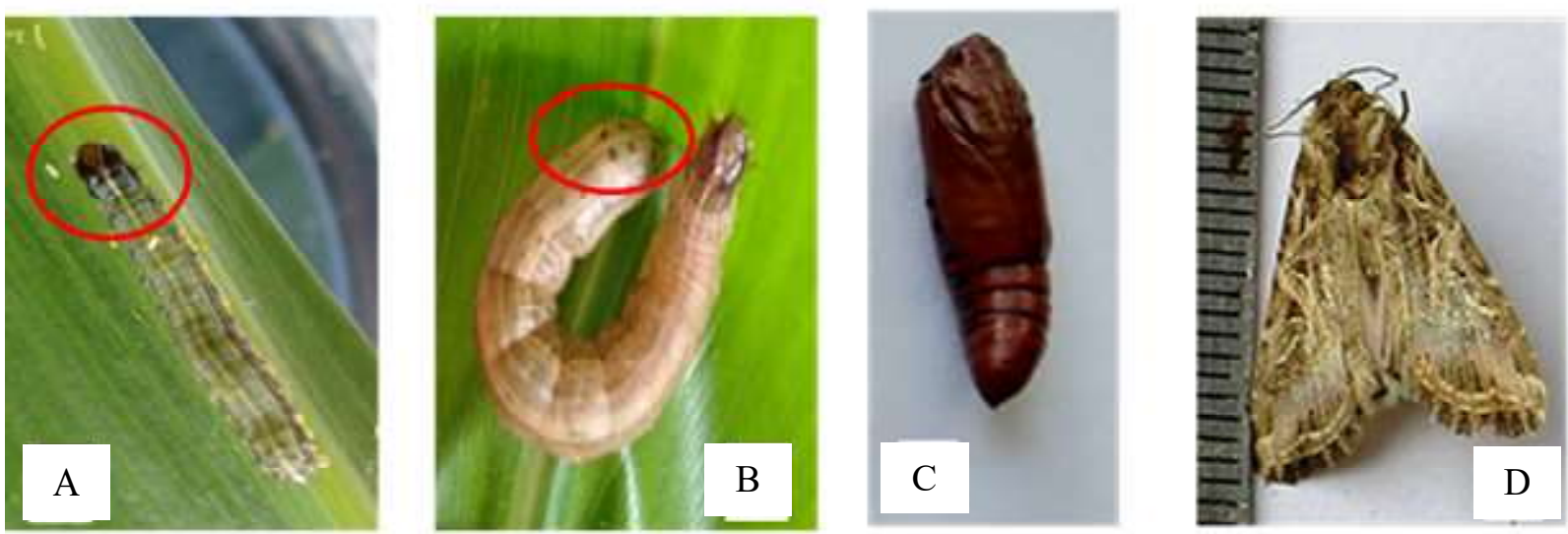

Figure 3. Spodoptera frugiperda. (A) 3rd instar larvae, (B) 4th instar larvae, the larvae had an inverted "Y" symbol on the head and 4 large spots (pinacula) on the segment 8 abdomen, (C) Pupa, (D) Imago.
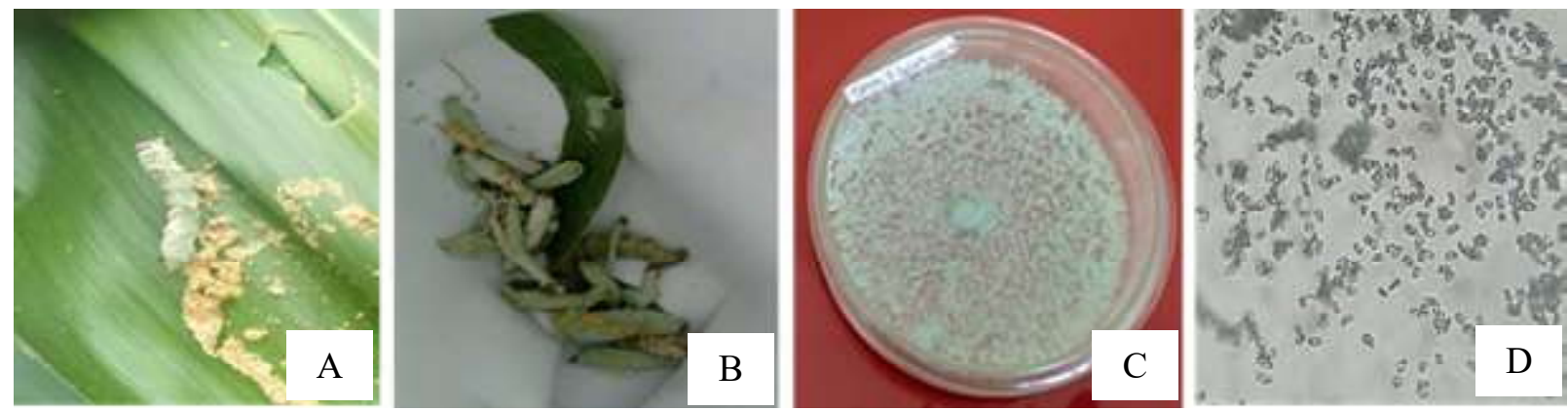

Figure 4. Entomopathogenic fungi. (A) and (B) S. frugiperda larvae infected by N. rileyi in the field, (C) Colony of $N$. rileyi on SMAY media, (D) Conidia of $N$. rileyi.

morphological data, the fungal pathogen infecting $S$. frugiperda larvae was $N$. rileyi. Morphologically, $N$. rileyi were septate, transparent, and branched hyphae. Branched conidiophores formed near the septa, with a number of 2-6 phialides. The phialides usually subglobose or short cylinders, with transparent and smooth wall. The conidia appears in chains, very ellipsoidal, smooth wall, and transparent. This research was in line with the results of Dutta et al. (2014).

The percentage of natural incidence of $N$. rileyi in $S$. frugiperda larvae were varied from 1.0 to $79.0 \%$. The highest natural incidence of $N$. rileyi were found in Bukit Barisan and Tugu Rejo (79.0\%), followed by Pulo Geto Baru (26.0\%), and Taba Mulan (5.3\%). The lowest incidence of $N$. rileyi was in Sidomulyo (1\%), while the percentage of corn crops damaged by $S$. frugiperda was ranged from 40 to $96 \%$ (Table 1 ). N. rileyi infecting $S$. frugiperda were not found in the Napal, Beringin Raya 1, and Beringin Raya 2 despite the percentage of S. frugiperda attacks reached 50.0, 50.0 and $74.0 \%$, respectively. This probably caused by environmental conditions that were less supportive for the development of entomopathogenic fungi. Merigi and Kabawetan Sub District has a higher altitude compared to other areas around (610-1077 $\mathrm{m}$ asl) (Table 1), so that the temperature is lower compared to other regions of Napal, South Seluma Sub District (44 m asl) and Beringin Raya, Muara Bangka Sub District (8.1-14.2 m asl).

The suitable areas for the development of fungi will cause natural and epizootic infections. The geographical location, climate, habitat, altitude, and $\mathrm{pH}$ of the soil or organic matter impact the presence of fungal species and responses of fungi species to these condition varies. Temperature also influences fungal efficacy (Abd El-Ghany, 1995; Abdel-Raheem 2020).

The potential of $N$. rileyi in Lepidoptera had been reported by Hamirbhai (2010) on Helicoverpa armigera with natural incidence reached $14.0 \%$. During this study, infection of $N$. rileyi on $S$. frugiperda varied in various areas due to the environmental conditions. This study was in line with Manjula et al. (2003) which stated that temperature, rainfall, and humidity showed a positive correlation with the incidence of disease in 
Table 1. Percentage of $N$. rileyi incidence and crops damage found in Bengkulu

\begin{tabular}{|c|c|c|c|c|c|}
\hline No & Location & $\begin{array}{l}\text { Altitude } \\
(\mathrm{m})\end{array}$ & Coordinate & $\begin{array}{l}\text { Crops } \\
\text { damage } \\
(\%)\end{array}$ & $\begin{array}{c}\text { Incidence } \\
\text { of } N . \text { rileyi } \\
(\%)\end{array}$ \\
\hline \multirow[t]{2}{*}{1} & $\begin{array}{l}\text { Sidomulyo, South Seluma Sub } \\
\text { District, Seluma District }\end{array}$ & 0 & $-4^{\circ} 6^{\prime} 18^{\prime \prime} \mathrm{S} 102^{\circ} 33^{\prime} 35^{\prime \prime} 172^{\circ}$ & 40.0 & 1.0 \\
\hline & $\begin{array}{l}\text { Napal, South Seluma Sub } \\
\text { District, Seluma District }\end{array}$ & 44 & $-4^{\circ} 5^{\prime} 57,64171^{\prime \prime} \mathrm{S} 102^{\circ} 33^{\prime} 43^{\prime} 61933^{\prime \prime} \mathrm{E}$ & 50.0 & 0 \\
\hline \multirow[t]{3}{*}{2} & $\begin{array}{l}\text { Pulo Geto Baru, Merigi Sub } \\
\text { District, Kepahiang District }\end{array}$ & 617 & $-3^{\circ} 30^{\prime} 53,76042^{\prime} \mathrm{S} 102^{\circ} 31^{\prime} 2^{\prime} 91328^{\prime \prime} \mathrm{E}$ & 62.0 & 26.0 \\
\hline & $\begin{array}{l}\text { Taba Mulan, Merigi Sub District, } \\
\text { Kepahiang District }\end{array}$ & 610 & $-3^{\circ} 29^{\prime} 52,15229^{\prime \prime} \mathrm{S} 102^{\circ} 30^{\prime} 23^{\prime} 7793 \mathrm{E}$ & 76.0 & 5.3 \\
\hline & $\begin{array}{l}\text { Bukit Barisan, Merigi Sub } \\
\text { District, Kepahiang District }\end{array}$ & 619 & $-3^{\circ} 30^{\prime} 16,25029^{\prime \prime} \mathrm{S} 102^{\circ} 30^{\prime} 23^{\prime} 7793 \mathrm{E}$ & 96.0 & 79.0 \\
\hline \multirow[t]{2}{*}{3} & $\begin{array}{l}\text { Beringin Raya 1, Muara Bangka } \\
\text { Hulu Sub District, Bengkulu City }\end{array}$ & 8.1 & $-3^{\circ} 45^{\prime} 27,49961^{\prime \prime} \mathrm{S} 102^{\circ} 15^{\prime} 40^{\prime} 51084^{\prime \prime} \mathrm{E}$ & 50.0 & 0 \\
\hline & $\begin{array}{l}\text { Beringin Raya 2, Muara Bangka } \\
\text { Hulu Sub District, Bengkulu City }\end{array}$ & 14.2 & $-3^{\circ} 44^{\prime} 43,83604^{\prime \prime} \mathrm{S} 102^{\circ} 15^{\prime} 38^{\prime} 42532^{\prime \prime} \mathrm{E}$ & 74.0 & 0 \\
\hline 4 & $\begin{array}{l}\text { Tugu Rejo, Kabawetan Sub } \\
\text { District, Kepahiang District }\end{array}$ & 1077 & $-3^{\circ} 35^{\prime} 19,84333$ 'S 102³7'39'38549’E & 90.0 & 79.0 \\
\hline
\end{tabular}

insects. Similarly, rainfall and humidity also play a role important for the development of entomopathogenic fungi in S. litura (Rachappa \& Lingappa, 2007). In addition, Choudhary et al. (2012) reported that temperature, humidity, and rainfall play an important role in the incidence, distribution, prevalence, and effectiveness of entomopathogenic fungi.

Unlike the use of chemicals pesticide, entomopathogenic fungi have advantages that can survive in nature, reduce repeated applications, save time, energy, costs, and preserve the environment so that it is beneficial for farmers. The high incidence of $S$. frugiperda larvae infected $N$. rileyi affected by rainfall and high humidity which suitable for the growth and development of the fungus. Raindrops help the conidia reached the leaf surface where insects feed, resulting in primary infection. Abd El-Ghany (1995) stated that low humidity has been considered of factors limiting the effectiveness and failures of field trials.

The $N$. rileyi had the ability to infect and caused epizootics naturally if the environmental conditions were suitable, especially high temperatures and humidity in the field.

Entomopathogenic fungi had a broad spectrum such as the ability to infect several species of insects with different states and cause epizootics under natural conditions. Fungal spores infected the insect through integument, multiply in various tissues in the body, and killed the insects by releasing toxins that cause tissue damage. Epizootics depend on the climate factors such as wind, rain, or frequency of contact between insects. The infected insects would stop eating, changing color (beige, reddish, or brown), and eventually die due to being colonized by a fungus. Moisture was very important for the success of fungi as biological control agents. This study showed the potential of $N$. rileyi in the management of $S$. frugiperda in the field. For areas that do not support the development of entomopathogenic fungi, irrigation will help farmers to create environmental conditions that are suitable for the development of $N$. rileyi, because it can reduce temperatures and increase relative humidity in areas that are less supportive. 


\section{CONCLUSION}

Incidence of entomopathogenic fungus $N$. rileyi occurred naturally in $S$. frugiperda larvae with infection rates ranged from 1 to $79 \%$. Meanwhile, the percentage of crops damage due to $S$. frugiperda ranged from 40.0 to $96.0 \%$. The highest natural incidence of $N$. rileyi were observed in the Village of Bukit Barisan and Tugu Rejo (79.0\%), followed by Pulo Geto Baru (25.0\%), and Taba Mulan (5.3\%) while the lowest incidence occurred in Sidomulyo, South Seluma Sub District, Seluma District 1.0\%. The infected larvae were not found in the Villages of Beringin Raya 1 and Beringin Raya 2, Muara Bangka Hulu Sub District, Bengkulu City and the Village of Napal, South Seluma Sub District, Seluma District, although the percentage of $S$. frugiperda attacks reached 50.0, 50.0 and 74.0\%.

\section{ACKNOWLEDGMENT}

We would like to thank the corn planters in the area of the study site for allowing us to do this research.

\section{REFERENCES}

Abd El-Ghany TM. 1995. Entomopathogenic Fungi and their Role in Biological Control. OMICS Group eBooks, California.

Abdel-Raheem M. 2020. Isolation, mass production and application of entomopathogenic fungi for insect pests control. In: El-Wakeil N, Saleh M, \& AbuHashim M (Eds.). Cottage Industry of Biocontrol Agents and their Applications. pp. 231-252. Spinger Nature, Switzerland.

Akutse Akutse KS, Kimemia JW, Ekesi S, Khamis FM, Ombura OL, \& Subramanian S. 2019. Ovicidal effects of entomopathogenic fungal isolates on the invasive fall armyworm Spodoptera frugiperda (Lepidoptera: Noctuidae). J. Appl. Entomol. 143(6): 626-634.

Baudron F, Zaman-Allah MA, Chaipa I, Chari N, \& Chinwada P. 2019. Understanding the factors influencing fall armyworm (Spodoptera frugiperda J.E. Smith) damage in African smallholder maize fields and quantifying its impact on yield. A case study in Eastern Zimbabwe. Crop Prot. 120: 141-150.

Choudhary JS, Prabhaker CS, Maurya S, Kumar R, Das B, \& Kumar S. 2012. New report of Hirsutella sp. infecting mango hopper Idioscopus clypealis from Chotanagpur Plateau, India. Phytoparasitica. 40(3): 243-245.

Chimweta M, Nyakudya IW, Jimu L, \& Mashingaidze AB. 2019. Fall armyworm [Spodoptera frugiperda (J.E. Smith)] damage in maize: management options for flood-recession cropping smallholder farmers. Int. J. Pest Manage. 66 (2): 142-154.

McGrath D, Huesing JE, Beiriger R, Nuessly G, TepaYotto TG, Hodson D, Kimathi E, Elias F, Obaje JA, Mulaa M, Mendes AP, Mabrouk AFA, \& Belayneh Y. 2018. Monitoring, surveillance, and scouting for fall armyworm. In: Prasanna BM, Huesing JE, Eddy R, \& Peschke VM (Eds.). Fall Armyworm in Africa: A Guide for Integrated Pest Management. First Edition. pp. 11-28. CDMX, CIMMYT. Mexico.

Cruz-Avalos AM, Bivián-Hernández MA, Ibarra JE, \& Rincón-Castro MCD. 2019. High virulence of mexican entomopathogenic fungi against fall armyworm, (Lepidoptera: Noctuidae). J. Econ. Entomol. 112(1): 99-107.

Dutta P, Patgiri P, Pegu J, Kaushik H, \& Boruah S. 2014. First record of Nomuraea rileyi (Farlow) Samson on Spodoptera litura Fabricius (Lepidoptera: Noctuidae) from Assam, India. Curr. Biotica. 8(2): 187-190.

Early R, González-Moreno P, Murphy ST, \& Day R. 2018. Forecasting the global extent of invasion of the cereal pest Spodoptera frugiperda, the fall armyworm. NeoBiota. 40: 25-50.

EPPO. 2019. Spodoptera frugiperda continues to spread in Asia. EPPO Reporting Service, No.2019/053. EPPO. Paris, France. https:// gd.eppo.int/reporting/article-6483.

Goergen G, Kumar PL, Sankung SB, Togola A, \& Tamò M. 2016. First report of outbreaks of the fall armyworm Spodoptera frugiperda (J.E. Smith) (Lepidoptera, Noctuidae), a new alien invasive pest in west and central Africa. PloS ONE. 11(10): e0165632.

Hamirbhai BA. 2010. Bio-efficacy of Nomuraea rileyi (Farlow) Samson against Helicoverpa armigera (Hubner) infesting pigeonpea. Dissertation. Junagadh Agricultural University, Junagadh. 
Huesing JE, Prasanna BM, McGrath D, Chinwada P, Jepson P, \& Capinera JL. 2018. Integrated pest management of fall armyworm in Africa: an introduction. In: Prasanna BM, Huesing JE, Eddy R, \& Peschke VM (Eds.). Fall Armyworm in Africa: A Guide for Integrated Pest Management. First Edition. pp. 1-10. CDMX, CIMMYT. Mexico.

IPPC. 2018. Report on fall armyworm (Spodoptera frugiperda) on the border of Thailand. IPPC Official Pest Report, No THA-03/1. FAO. Rome, Italy. https://www.ippc.int/en/countries/ thailand/pestreports/2018/12/first-detection-offall-army-worm-on-the-border-of-thailand/.

Lestari P, Budiarti A, Fitriana Y, Susilo FX, Swibawa IG, Sudarsono H, Suharjo R, Hariri AM, Purnomo, Nuryasin, Solikhin, Wibowo L, Jumari, Hartaman M. 2020. Identification and genetic diversity of Spodoptera frugiperda in Lampung Province, Indonesia. Biodiversitas. 21(4): 1670-1677.

Nonci N, Kalqutny SH, Mirsam H, Muis A, Azrai M, \& Aqil M. 2019. Pengenalan Fall Armyworm (Spodoptera frugiperda J.E. Smith) Hama Baru pada Tanaman Jagung di Indonesia. Balai Penelitian Tanaman Serealia. Badan Penelitian dan Pengembangan Pertanian. Kementerian Pertanian, Jakarta.

Maharani Y, Dewi VK, Puspasari LT, Rizkie L, Hidayat Y, \& Dono D. 2019. Cases of fall army worm Spodoptera frugiperda J.E. Smith (Lepidoptera: Noctuidae) attack on maize in Bandung, Garut and Sumedang District, West Java. J. Cropsaver. 2(1): 38-46.

Mallapur CP, Naik AK, Hagari S, Praveen T, Patil RK, \& Lingappa S. 2018. Potentiality of Nomuraea rileyi (Farlow) Samson against the fall armyworm Spodoptera frugiperda (J E Smith) infesting maize. J. Entomol. Zool. Stud. 6(6): 1062-1067.

Manjula K, Nagalingam B, \& Arjuna RP. 2003. Occurrance of Nomuraae rileyi on Spodoptera litura and Helicoverpa armigera in Guntur District of Andhra Pradesh. Ann. Plant Prot. Sci. 11(2): 224-227.

Moanaro, Kumari A, Choudhary JS, Pan RS, \& Maurya S. 2017. Natural incidence of Nomuraea rileyi, an entomopathogenic fungus on Spodoptera litura infesting groundnut in eastern region of India. The Bioscan. 12(2): 843-846.

Rachappa V \& Lingappa S. 2007. Seasonality of Nomuraea rileyi (Farlow) Samson in northern trasitional belt of Karnataka. Ann. Pl. Protec. Sci. 15(1): 68-72.

Sharanabasappa, Kalleshwaraswamy CM, Asokan R, Swamy HMM, Maruthi MS, Pavithra HB, Hegde K, Navi S, Prabhu ST, \& Goergen G. 2018a. First report of the fall armyworm, Spodoptera frugiperda (J.E.Smith) (Lepidoptera: Noctuidae), an alien invasive pest on maize in India. Pest Manag. Hort. Ecosyst. 24(1): 23-29.

Sharanabasappa, Kalleshwaraswamy CM, Maruthi MS, \& Pavithra HB. 2018b. Biology of invasive fall army worm Spodoptera frugiperda (J.E. Smith) (Lepidoptera: Noctuidae) on maize. Indian J. Entomol. 80(3): 540-543.

Shylesha AN, Jalali SK, Gupta A, Varshney R, Venkatesan T, Shetty P, Ojha R, Ganiger PC, Navik O, Subaharan K, Bhaktavatsalam N, \& Ballal CR. 2018. Studies on new invasive pest Spodoptera frugiperda (J.E. Smith) (Lepidoptera: Noctuidae) and its natural enemies. J. Biol. Control. 32(3): 145-151.

Trisyono YA, Suputa, Aryuwandari VEB, Hartaman M, \& Jumari. 2019. Occurrence of heavy infestation by the fall armyworm Spodoptera frugiperda, a new alien invasive pest, in corn in Lampung Indonesia. Jurnal Perlindungan Tanaman Indonesia. 23(1): $156-160$.

Wanasinghe VKASM, Chanchala KMG, Karunathilake AP, Nikpay A, \& Nugaliyadde L. 2019. First report of fall army warm, Spodoptera frugiperda (Lepidoptera: Noctuidae) in sugarcane in Sri Lanka. International Sugar and Sugarcane Conference. Pattaya, Thailand.

Yee KN, Aye MM, Htain NN, Oo AK, Kyi PP, Thein MM, \& Saing NN. 2019. First detection report of the Fall Armyworm Spodoptera frugiperda (Lepidoptera: Noctuidae) on maize in Myanmar. https://www.ippc.int/static/media/files/pestreport/ 2019/01/11/Detection report of FAW in Myanmar.pdf. 